\title{
New perspectives on public finance: recent achievements and future challenges
}

\author{
Joseph E. Stiglitz \\ Columbia University, Graduate School of Business, Uris Hall, New York, NY 10027, USA
}

\begin{abstract}
The advances in the economics of the public sector during the past quarter century have been as pronounced as in any field within economics. Public finance has become a rigorous branch of applied microeconomics, incorporating the best thinking and most advanced tools of both theoretical economics and econometrics. In the remarks below, I will focus on a few key areas in applied and theoretical tax and expenditure policy, drawing both upon the academic work of myself and others, and my experiences in the policy arena, both as Chairman of the Council of Economic Advisers and as Chief Economist of the World Bank. I shall address both the questions of what we have learned in the past few decades as well as the questions where further research is needed.

(C) 2002 Elsevier Science B.V. All rights reserved.
\end{abstract}

Keywords: Pareto-efficient taxes; Market failures and taxes; Corruption; Political economy of tax reform; Transparency and taxes

\section{Tax theory}

\subsection{Pareto efficient taxation}

One of the most significant insights - obvious from current perspectives was the recognition that all taxes induce distortions, but that the total dead weight loss of the tax system was not minimized by minimizing the number of

E-mail address: jes322@columbia.edu (J.E. Stiglitz). 
distortions. ${ }^{1}$ Perhaps the second most significant insight - again obvious from current perspectives - was that one could approach efficient taxation using the same concepts that economists had long used in analyzing efficient allocative mechanisms, that is pareto efficient tax structures were those such that no one could be made better off, given the technological and other constraints, without making someone else worse off. With a specified social welfare function, one could choose which among these Pareto efficient tax structures maximized social welfare. ${ }^{2}$ The third important insight was the recognition of the key role played by these constraints, especially the informational constraints. Lump sum taxation was clearly Pareto efficient, if the government had all the information about each individual and could tax each differentially. However, if, for instance, government could not observe each individual's ability, but could observe his income and expenditures on particular commodities, then taxes had to be based on those variables. But in that case, it turned out Pareto efficient commodity tax structures did not look anything like those that Ramsey had characterized; for instance, if there was separability between leisure and consumption, then there should be no commodity taxation at all. Ramsey's analysis (and that of Diamond and Mirrlees) had an additional implicit and unrealistic constraint: that income could not be taxed. 3

\subsection{The problem of robustness}

This highlighted one of the most vexing aspects of these advances in the theory of taxation: even the few qualitative results turned out not to be robust, even though the way of approaching the problems of taxation proved very insightful. To cite but two other examples: the powerful Diamond-Mirrlees theorem on the desirability of production efficiency, which implied that one should not have a corporate income tax nor tariffs, turned out to require $100 \%$ profit taxation and the ability to impose a complete set of commodity taxes. ${ }^{5}$ The Mirrlees result that the

\footnotetext{
${ }^{1}$ Ramsey (1927). While Ramsey's analysis was embedded in Pigou's classic work (1918), and reportedly drew the attention of Samuelson in a memorandum written during World War II, and was seemingly independently discovered by Boiteaux (1956) in the context of regulation, it seemingly did not enter into the mainstream of American public finance until Diamond and Mirrlees' classic paper (1971), which, for the first time, set the issues in the context of a general equilibrium model.

${ }^{2}$ The concept of Pareto efficient taxation was developed and reviewed in Stiglitz (1982a, 1988) and Brito et al. (1990).

${ }^{3}$ Even if there was not a Pareto efficient income tax, but a linear or progressive income tax, the commodity tax structure looked markedly different from that of Ramsey and Diamond and Mirrlees. See, e.g. Atkinson and Stiglitz (1976) and Stiglitz (1988, 1998a).

${ }^{4}$ In developing countries, it is often more difficult to impose an income tax. But even then the Ramsey analysis has limited applicability, because the structure of the economy is so markedly different; one has to worry about impacts, for instance, on migration, and, if there is unemployment, for instance, because of efficiency wages, the impact of different taxes on that. See Sah and Stiglitz (1992).

${ }^{5}$ See Dasgupta and Stiglitz (1971, 1972), Naito (1999).
} 
limiting marginal tax rate with an optimal utilitarian tax was zero at first looked like it held far more generally than in the model he had analyzed, analyzing optimal taxation with a utilitarian social welfare function - it held for any Pareto efficient tax structure; but then it turned out that it was far less general — it held only if relative wages were fixed, unaffected by, say, the relative supplies of skilled and unskilled labor, a highly implausible assumption. ${ }^{6}$

\subsection{Robustness in incidence analysis}

The sensitivity of the results on what was a desirable tax structure carried over to the theory of tax incidence, with many of the insights yet to be fully integrated into standard policy analysis. If imperfect information played a central role in constraining tax systems, it similarly played a central role in affecting economic organization. Agency problems abound. And agency problems have marked effects on economic behavior, and therefore on the incidence of taxation. To take but one example: Earlier analyses of the incidence of the corporation income tax were befuddled by the fact that in a standard neoclassical model, firms could borrow as much as they wanted at the margin; as a result, marginal finance could be thought of as debt finance; but with interest deductibility, this meant that there was no marginal distortion. But with imperfect information, there could be credit rationing (Stiglitz-Weiss, 1981), and a massive literature confirmed that credit rationing was important, particularly for small and medium sized firms. Moreover, many firms were also equity constrained ${ }^{7}$, that is, could not issue more equity shares. Therefore, they had to rely on retained earning for investment. In this theory, then, it is the average tax rate, not the marginal tax rate, that matters. ${ }^{8,9}$

\footnotetext{
${ }^{6}$ And indeed, under plausible assumptions it turned out that Pareto efficient taxation required negative limiting marginal tax rates, a highly political unsavory result. This result also does not hold if there is an open-ended probability distribution at the top. (Then the limiting tax rate can be quite high. See Diamond (1998) and Saez (2001) If earnings are risky and there is no market to ensure labor earnings then too the top rate can be much higher. See Varian (1980), Stiglitz (1982a).

${ }^{7}$ See Greenwald et al. (1984) and Myers and Majluf (1984).

${ }^{8}$ Some empirical work verified this perspective: see, in particular, Fazzari et al. (1988). For theoretical analyses, see, e.g. Greenwald and Stiglitz (1987, 1989).

${ }^{9}$ There were, in addition, a number of other problems with the theory, not all of which have yet been fully resolved (see Stiglitz, 1998a). For instance, as taxation occurs over time, optimal taxation at date $t$ should incorporate information revealed in previous dates; individuals, knowing that, will alter their behavior. There are thus important issues associated with dynamic consistency in optimal taxation over time. (See Brito et al., 1991). A second example: The mathematical structures underlying optimal tax theory often imply that some form of randomization would be desirable, but this seems as politically unpalatable as a zero marginal tax rate at the top. See Stiglitz (1983a), Brito et al. (1995).
} 


\subsection{Agency theory in the public sector}

Agency problems arise in the public sector no less than they do in the private. There has been increasing awareness of the prevalence of corruption in many developing countries, and the consequences for development. ${ }^{10}$ While there was considerable progress during recent decades in understanding the implications of transactions costs (including compliance costs) in the design of tax systems and the consequences of tax avoidance and evasion ${ }^{11}$, there has been much less progress in the analysis of corruption resistant tax systems. This is a subject of enormous practical as well as theoretical concern. The standard prescriptions, e.g. of the IMF, in response to problems of insufficient revenue due to incomplete enforcement of the tax laws is to increase the power of the tax police (the internal revenue services), but in countries with inadequate and corrupt judiciary, this has often done more to increase corruption, to enhance the ability of the government officials to extract money for their own purposes from the taxpayer than it has done to increase the revenues of the public fisc. There has been a further indirect effect in creating a more adverse business climate. The scope for corruption is affected by the ease with which the variables which determine the tax base are determined; this affects the discretion at the disposal of the tax administrator. This is another example of how modern information economics has affected modern tax theory: traditional (Pareto) optimal tax theory focused on the restrictions imposed by what is observable. But in many, perhaps most, cases, the issue is not just observability. It is the costs and accuracy of observations. The costs of observation affect the transactions costs of the system; noisy observations can be thought of as resulting in a form of random taxation, which (the problems posed by nonconvexities aside) would normally be thought of as lowering social welfare; but imperfect observability also enhances opportunities for corruption.

\subsection{Reforms that increase equity and efficiency}

Agency theory had one further extremely important implication for tax policy: traditionally, it had been argued in theory that issues of distribution and efficiency can be separated, and that in practice, in the absence of lump sum taxes, there was a trade-off. Agency theory emphasized that there were some redistributions which both increased equity and efficiency (see Stiglitz, 1998c and other papers in the Birdsall et al. volume). A land reform that took land from a few landlords and

\footnotetext{
${ }^{10}$ See, for instance, the World Development Report (1998).

${ }^{11}$ See, for instance, Slemrod and Yitzhaki (2000), Andreoni et al. (1998), and Stiglitz (1983b, 1985).
} 
gave it to the tenant farmers would increase social welfare with any equalitarian social welfare function. ${ }^{12-14}$

\subsection{The unit of analysis: looking inside the household}

An area that economists are just beginning to explore ${ }^{15}$, in which similar issues arise, concerns the unit of analysis. When attention is turned from the household to the individual, it becomes clear that regardless of the model of the family that one employs (i.e. whether it is a bargaining model, or an integrated household maximizing a social welfare function ${ }^{16}$ ) the incidence of tax and expenditure policies may look markedly different. For instance, the corporate income tax encourages consumption inside the corporation, and thus, even were it reducing inequalities between high income households (with corporate capital) and low income households (those without), may increase inequality among individuals (using standard measures.) ${ }^{17}$

\subsection{Imperfect competition}

Information problems were not the only reason for dissatisfaction with the competitive equilibrium model that underlay most incidence analysis. Many markets are characterized by imperfections of competition, and incidence of taxes and subsidies in such markets may differ markedly from that in competitive markets. $^{18}$

\footnotetext{
${ }^{12}$ There were other instances, arising out of other market imperfections (some of which could be related to imperfections of information): educational programs, like Head Start, that enhanced opportunities for low income children, seemed to yield high returns, and thus increased both equity and efficiency.

${ }^{13}$ Because with imperfect information and incomplete markets, market failures are pervasive (the economy is essentially never constrained Pareto efficient), the scope for corrective taxation is much larger; there is even considerable scope for redistributive taxation that, at the same time, makes everyone better off. See Greenwald and Stiglitz (1986), Arnott and Stiglitz (1986), Stiglitz (1998a).

${ }^{14}$ Another major advance in the last quarter century is in the analytic tools with which we assess inequality, growing out of the work of Atkinson (1970), building on Rothschild and Stiglitz' analysis of the measurement of risk. That work was subsequently extended by Dasgupta et al. (1973) and Rothschild and Stiglitz (1973). In the concluding sections of this paper, I remark on some of the limitations of that approach.

${ }^{15}$ Though which was addressed in an unpublished paper a quarter century ago (Apps and Stiglitz, 1979).

${ }^{16}$ See World Bank (2001).

${ }^{17}$ There is a parallel between the earlier analysis of the impact of taxation in an economy with a large informal sector and the analysis here. Household production can be viewed as a particular form of the 'informal' sector, one that remains important even in advanced industrial economies, and one has to be sensitive to the effect of taxation on the formal sector in shifting production into this informal sector.

${ }^{18}$ See, for instance Stern (1987) and Cremer and Thisse (1994). Hoff and Stiglitz (1997) analyze the incidence of interest rate subsidies in the context of a monopolistically competitive model of the capital model, with markedly different results from those that emerge from the standard competitive model.
} 


\subsection{Tax paradoxes: insights in the limitations of the old paradigms}

The discrepancy between the predictions of the simple theories and observations was brought home by a number of tax paradoxes, which did as much to highlight limitations in the standard model of the economy as they did those of tax theory. The most widely discussed was the dividend paradox (Stiglitz, 1973) - the observation that there are ways of transferring funds from the corporate to the household sector which result in less of a tax burden than dividends, and yet firms continue to pay dividends. There are other paradoxes, relating to accounting practices (in inflationary periods, LIFO results in less of an overall tax burden than FIFO, though many firms continued to use FIFO; there are managerial compensation schemes which provide as strong incentives as current schemes (and less risk bearing), but entail less tax burden ${ }^{19}$ ). It is noteworthy that as some of these paradoxes have been widely discussed, they have begun to disappear, reinforcing the conclusion that, in my judgment, the numerous attempts to resolve the paradoxes are unconvincing ${ }^{20}$. (There remains a debate about whether the persistence of these practices is a result of inefficient (non-value maximizing) firms, or value maximizing firms exploiting irrational investors. My unscientific interviews with firm managers has led me to the conclusion that both are true: most were unaware of the issues, but when they were pointed out, concluded that they would continue to behave as they had, because the 'market' would not understand any change in practices, as beneficial as it might be to shareholders in the longer run. The firms that changed most quickly were those that were closely held.)

\section{Taxation in practice}

\subsection{The conflict between trends in theory and trends in practice}

If the thrust of the new public finance was to argue that in general, non-linear and highly differentiated taxes were desirable, the thrust of tax reform was to simplify the tax code and reduce differentiation. In Europe there was a movement towards greater reliance on a single rate VAT, which reduced at least the seemingly progressivity and (with a few exceptions) the role differentiated commodity taxation. This movement was partly based on the difficulties of even advanced industrialized countries in implementing a comprehensive progressive income or expenditure tax. Elsewhere, the IMF pushed countries which were even unable to implement a comprehensive VAT in that direction, seemingly oblivious to the fact

\footnotetext{
${ }^{19}$ See Stiglitz (1982b, 1987c).

${ }^{20}$ See, for instance, the brief discussion in Stiglitz (2000a). The fact that there has been a marked change in distribution to more tax advantaged forms is consistent with the views presented here.
} 
that when the tax is collected only from (a part of) the formal sector, typically $50 \%$ or less of GDP, it was highly distortive, and worse, suppressed the very sectors that should have been encouraged as part of the process of development. ${ }^{21}$

Similarly, while optimal commodity taxation suggested that it would be desirable to tax 'bads' (like pollution) ${ }^{22}$, the attempt to introduce a carbon tax by the Clinton administration was sorely beaten back. In that case, the political economy of tax reform was clear: the vested interests who saw themselves disadvantaged by the tax mobilized far more effectively than the public interest groups that were concerned about the environment.

\subsection{The difficulties of engendering support for good tax policies}

Other instances of seemingly sensible tax policy were stymied either because they were sensible - the lack of rents entailed a lack of support - or because of shared popular misunderstanding. For instance, the Clinton proposal to stimulate the economy through a net investment tax credit had the virtue of providing a high level of 'bang for the buck', strong marginal incentives without large losses to the Treasury. But that was precisely why it failed to win business support - it gave them too little. While the corporate income tax is widely criticized by economists because of its distortions, the inequities associated with double taxation, and because of its lack of transparency (the difficulty of telling who really bears the incidence, with the incidence likely being either on workers ${ }^{23}$ or entrepreneurship $^{24}$ ), it has proved difficult to abolish, or even to reform substantially, partly because corporate interests believe it is a tax on them, and therefore they have fought hard against it; but the very fact that they have done so has reinforced the view of other groups that it is a tax on corporate interests, and therefore it would be inequitable to abolish it.

\subsection{Lessons from the 1986 tax reform}

The one seemingly major 'successful' tax reform ${ }^{25}$ in the US, that of 1986, should have brought home three lessons: The first is that there are large capital asset effects associated with any tax reform, and there are real and distributional

\footnotetext{
${ }^{21}$ See Emran and Stiglitz (2000).

${ }^{22}$ See Sandmo (1975) and Stiglitz (1998a).

${ }^{23}$ Assuming that the elasticity of supply of capital is fairly large.

${ }^{24}$ See Stiglitz (1973) Because of interest deductibility, the tax is not a tax on capital at the margin, even when the supply of capital is not perfectly elastic, and accordingly is an infra-marginal tax.

${ }^{25}$ How significant it was in practice is a question raised by the some of the papers in the Journal of Economic Perspectives symposium on the tax reform (Summer, 1987). Still, while the changes in distribution and incentives may not have been as large as its proponents suggested, the elimination of some of the loopholes had some effects - with some blaming the real estate collapse and the subsequent recession on the 1986 tax reform.
} 
consequences that result. ${ }^{26}$ Second, it is hard to design revenue neutral, let alone a revenue and distributional neutral tax reform that will muster support. The passage of the 1986 tax reform was partly based on the smoke and mirrors of accounting tricks, partly based on the lack of transparency of the corporate income tax. An increase in the corporation tax helped pay for the overall reduction in the individual income tax. Of course, individuals pay the corporate income tax; but because they do not perceive that to be the case, enough people can believe that someone else is paying the tax ('the corporation') that they can believe that they are net winners. And that brings me to the third point: given the uncertainty about the consequences, in fact the expected gains from reform have to be positive for the reform to muster support. But that is impossible in a revenue neutral tax reform with rational expectations. Thus, either there has to be some sleights of hand - as in 1986 - or some tax reduction. Given the budget stringency during the first Clinton administration, it was impossible to have anything but a revenue neutral tax reform; and this effectively precluded tax reform. But the lessons of 1986 seemed to have been lost on the Bush administration, which first pushed forward a large tax cut, and following that - when there was no money left in the till, began to discuss tax reform, e.g. reduction or restructuring corporate income taxes.

\subsection{A tax reform for the future}

Equally sad, and hard to reconcile with standard approaches to political economy, was the failure of Clinton in his second term, as the budget surpluses loomed on the horizon, to try to push forward with a major tax reform more consistent with Democratic principles. I and others had proposed a reform that would have both reduced compliance and administration costs and lack of support for 'Democratic' expenditure policies arising in part from the intrusive nature of the Internal Revenue Service. While most Americans pay relatively small amounts in income taxes, their dislike of the individual income tax is related to the fears that it invokes as much as it is to the amounts extracted from them. Increasing the standard deduction to, say, $\$ 90000$ would have removed two thirds or more of all taxpayers from the rolls, and at the same time, would have eliminated for most of the remaining taxpayers all the distortions associated with the current income tax. It would have, furthermore, simplified the administration of the code. The resulting revenue gap could be made up by a combination of a broad based VAT (or an even broader based GDP) tax and environmental taxes. Still broader political support

\footnotetext{
${ }^{26}$ These consequences would not occur, or would be far less important, in the typical neoclassical model, but are of first order importance, e.g. in models with imperfect capital markets arising from imperfect information. See, e.g. Greenwald and Stiglitz (1993).

It is remarkable that these effects often remain ignored by advocates of policy reforms, e.g. at the IMF, who seem particularly insensitive to the importance of their implications for the timing, sequencing, and pacing of reform.
} 
could have been had by a slight reduction in the marginal rates of remaining payers of the individual income tax. The Treasury opposed discussions of tax reform, and it was never clear whether this came from a natural conservatism, from a worry that tax reform would risk some of the tax privileges of the corporate and financial interests from which they drew their support (as the 1986 reform had), ${ }^{27}$ or whether it was based on a political calculus that such reforms would fail to win enough support in a Republican controlled congress to win passage. Still, had the Administration brought forward such a tax reform proposal, it would have put on the table a viable alternative to the tax bill that was passed.

\subsection{Towards a more general theory of tax reform}

One of the important lessons to emerge from the experiences of attempted tax reforms of the past quarter century is how hard it is to effect change. It is not easy to translate the ideas that are beloved by economists into legislation, whether it is base broadening (the comprehensive income tax) or efficiency enhancing (the consumption tax or environmental taxes - taxing bads rather than goods). ${ }^{28}$

This has motivated research in reform. There are two strands of this research to which I wish to call attention.

There have been some significant advances in the general theory of tax reform (and reform more broadly) - even when we cannot delineate or describe easily the 'optimal' tax policy we may be able to describe reforms which are welfare improving under a weak welfare criteria (Pareto efficiency, equalitarian social welfare functions) ${ }^{29}$.

To me, the most significant challenges to those who wish to understand how to improve policy are the following two: Having argued that the 'optimal' tax policy is highly sensitive to the constraints, the question is, what are the relevant constraints? Repeatedly, I have seen what had previously been taken as a political

\footnotetext{
${ }^{27}$ Certainly, Treasury opposed even the use of the term 'corporate welfare,' as if it would ignite unnecessarily class warfare or consciousness.

${ }^{28}$ The consumption tax was supported in terms of encouraging growth (since savings were exempt), enhancing efficiency (since it eliminated the intertemporal distortions in consumption) and transactions costs (since much of the complexity of taxation is related to the taxation of capital.) The intellectual foundations were somewhat weaker than its proponents would admit, since it was only under somewhat restrictive conditions that it could be shown that it was optimal not to tax interest income. (See, e.g. Atkinson and Stiglitz, 1976 and Stiglitz, 1998a).

${ }^{29}$ For instance, there are conditions under which we can say that raising the tax on the least taxed commodity and lowering the tax on the most taxed commodity are welfare enhancing. See, e.g. Hatta (1986). But, unfortunately, results obtained to date have limited applicability, for many of the reasons cited above: the models often assume a structure in which the optimal tax is proportional taxation (i.e. there is a fixed factor, taken as the numeraire, so that proportional taxation is equivalent to a tax on that fixed factor, and therefore non distortionary; it is remarkable how difficult it is, even then, to be sure that a movement towards proportionality is welfare enhancing. See, e.g. Emran and Stiglitz (2001) in the context of a developing country where there is a large informal sector that cannot be taxed directly.
} 
constraint seemingly vanish, replaced by some new alleged constraint. It is clear that political processes cannot handle well 'complexity' — though they can clearly go beyond the simplicity of a single tax rate.

Secondly, while traditional normative theories often seem to ignore political processes, it is clear that one can do more than just describe the evolution of the economy. There are ways of affecting that evolution; it is clear that change is affected by perceptions of equity, and that information about incidence, and the way that information is presented, can affect those beliefs. A more complete theory of reform, that would inform those wishing to affect change about the circumstances under which change can most likely be affected, how to create those circumstances, and how to enhance the likelihood of reform remains one of the great challenges for the coming decade. I shall have a few more words to say about this at the end of the section.

\section{Expenditure policy: theory and practice}

Advances in the analysis of expenditure policy paralleled many of those in tax policy, with similar gaps between practice and theory. The market failures approach provided the unifying theory that was missing in earlier accounts of the role of government, identifying areas in which markets by themselves fail to provide efficient outcomes. ${ }^{30}$ But while the market failures approach has dominated normative theoretical discussions over the past half-century, it has confronted three problems.

\subsection{Limitations to the market failure approach: the pervasiveness of market failures}

First, it is now recognized that market failures are pervasive - markets do not result in (constrained) Pareto efficient outcomes whenever markets are incomplete or information is imperfect, that is, always (Greenwald and Stiglitz, 1986, 1988). Such a wide compass for intervention provides insufficient guidance to what government should do.

\subsection{Limitations to the market failure approach: government failures}

Secondly, there has been an increasing recognition of the limitations of government, of government failures that to some degree parallel those of the

\footnotetext{
${ }^{30}$ It is worth contrasting the standard textbook treatment of, say, 1960 - provided by Musgrave (1959) — with more recent accounts, e.g. Atkinson and Stiglitz (1970) or Stiglitz (1986, 2000a). Musgrave discussed the allocative role of government, as one of the three branches, or functions, of government, but did not explicitly relate those allocative roles to the failure of markets to solve the resource allocation problems efficiently.
} 
market. But much of the analysis of public failures remains at an unsophisticated level; for instance, the notion that political competition will result in full rent dissipation $^{31}$ assumes that there is perfect competition in rent seeking; but political competition is probably even more imperfect than economic competition, and even small sunk costs can result in the persistence of large economic rents. ${ }^{32}$

But while it was important to recognize that there were public failures as well as private, understanding the nature of those failures is at a far more rudimentary stage, though there have been some advances. We understand, for instance, why there is a need for collective action (e.g. free rider problems), that to avoid these problems governments have to be given powers that are greater than those given to any private individual or group (e.g. the power to tax or the power to proscribe), that these powers have often been abused, and that therefore constraints on government action are imposed. While the unique powers of the government allow it to do things that the private sector cannot do, the constraints put the government at a distinct disadvantage. There are other limitations facing government, e.g. in making commitments. The government enforces contracts made by private parties, but each government is sovereign, and cannot commit a subsequent government, though it can make change difficult. ${ }^{33}$ Some of the seeming public failures may be a consequence of inherent limitations of government, but some can be rectified. ${ }^{34}$ While there has been some progress in identifying some of the inherent limitations, much less progress has been made in understanding how to mitigate their consequences. There are ways that government can make partial commitments, by increasing transactions costs, and ways of designing incentive compatible mechanisms within the public sector (i.e. where, given the reward structures of government officials or interest groups, they have an incentive to carry out the promised policies), but these remain far from well understood. ${ }^{35}$ More broadly, identifying how performance in the public sector can be improved, remains one of the key theoretical and practical issues of the future.

To some extent, the reforms that were part of the reinventing government initiative headed by Vice-president Gore during the Clinton Administration represented an example where practice preceded theory (though many of the ideas were contained in Stiglitz, 1991). The initiative tried to identify ways of increasing the efficiency and efficacy both of expenditure and regulatory policies, employing market based mechanisms, and to make government agencies more responsive to those that they were supposed to serve, with remarkable success in some areas, such as Social Security. Government procurement reform, which recognized the limitations of competitive auctions and substituted off-the-shelf items where prices

\footnotetext{
${ }^{31}$ See Krueger (1974).

${ }^{32}$ Stiglitz (1987a,b,c).

${ }^{33}$ These ideas are elaborated on at greater length in Stiglitz (1989).

${ }^{34}$ For instance, there is far more opportunity for the use of competition and market based mechanisms than has traditionally been the case.

${ }^{35}$ See Aoki et al. (1997).
} 
were disciplined by the competitive market place, reflected a new awareness of the complexity of market processes, as did the increasingly sophisticated rules for spectrum auctions. The debate about privatization vs. corporatization or other forms of providing incentives and constraints within the public sector too seemed to outpace discussions within the academic literature. ${ }^{36}$

\subsection{Limitations to the market failure approach: why are seemingly Pareto improving reforms not adopted?}

Thirdly, and relatedly, many of the arenas in which government has entered actively, and more importantly, the ways in which it has entered, do not comport well with the market failure perspectives. In many cases, the government exacerbates the market failures; in some cases, there would seem to be reforms which would be Pareto improving which cannot be effected, though simplistic analyses would suggest that such reforms would be unanimously agreed upon. Elsewhere, I have put forward some hypotheses about why this might be the $\operatorname{case}^{37}$ : interest groups realize for instance, that the political process is dynamic, and they are concerned about the long run; thus, if a reform makes a certain subsidy that was hidden more transparent, or it results in the formation of new coalitions, it can adversely affect their long run prospects.

\subsection{Integration of government programs}

Earlier, I noted the difficulties of enacting 'sensible' tax reforms. Similar issues arise on the expenditure side. For instance, while economic theory - and common sense - would seem to argue for an integration of tax and redistributive programs, efforts, e.g. during the Clinton administration, even to integrate the various redistributive programs failed. Institutional political reasons, the fact that the food stamp program was supported by agriculture, the housing program by the real estate industry, etc. - provided the obvious explanation, but did not provide clear guidelines about how to create a more efficient and effective system. Meanwhile, theoretical advances helped identify the benefits that accrue from, say, an integrated public old age pension, unemployment, and disability programs (a variant of the Singapore provident fund), enabling the system to provide a higher level of risk mitigation for any level of attenuation of incentives. ${ }^{38}$

\footnotetext{
${ }^{36}$ See, for example, the National Partnership for Reinventing Government (1997) annual report.

${ }^{37}$ Stiglitz (1998b).

${ }^{38}$ See Stiglitz and Yun (2001). Integration is more important, the greater individuals come to rely on public pension programs. Most episodes of unemployment represent a relatively small fraction of individual's lifetime income, and, were capital markets perfect, could easily be absorbed. The social cost of unemployment is thus largely related to the inability to smooth consumption; but current unemployment programs, while they smooth consumption, have adverse effects on incentives.
} 


\subsection{Agriculture reform and dynamic consistency}

America's agricultural subsidy program also nicely illustrates the problems of reform. The problems with the system are widely recognized: the distortions, the inequities (with much of the proceeds going to upper income farmers), the adverse effects on the environment. It is not difficult, it would seem, to design Pareto improvements. The 1996 law superficially seemed to do that: it represented a one time compensation to farmers, in return for a lowering of distortionary subsidies in the future. But the reform was not dynamically consistent. The farmers accepted the compensation up-front, but when they were confronted with adverse conditions a couple years later on, they obtained further relief.

\subsection{Privatization and the appropriate scope of public production}

Traditionally, public expenditure theory focused on what the government should finance or subsidize. But one of the major policy issues in the last quarter century has been the role of government in production. A major change in Europe and Japan has been privatization, and even when responsibility for production remains in the public sector, contracting out for services. More recently, there have been a variety of forms of public/private partnerships. Privatization has extended from realms in which there was no obvious role for government, e.g. the production of steel, to those in which there almost inevitably will be some role for government (e.g. natural monopolies, prisons), and the question is what that role should be.

Agency theory suggests that there are parallel problems in large organizations (e.g. in delegation and providing incentives) whether they are in the public or private sector. ${ }^{39}$ The one general theorem on privatization, that of Sappington and Stiglitz (1987), suggests that the conditions under which privatization adequately resolves problems of public interest are closely parallel to those of the fundamental theorems of welfare economics, e.g. no externalities, complete markets, and perfect information. While volumes described the lower average performance of public bodies supplying particular services, that literature did not adequately address the question of why it was that some of the most efficient firms (e.g. in steel) were in the public sector, and whether there were particular practices which might easily be imitated that accounted for their greater efficiency. Nor did the critics of public ownership seem to anticipate either the problems associated with the privatization process itself or the problems that were repeatedly encountered after privatization, which in many countries in many areas led to a subsequent renationalization (at great public expense.) Problems of corruption which eviscerated the effectiveness of public corporations were amplified by the privatization process: government officials got to divert for their own benefit not only the

\footnotetext{
${ }^{39}$ See, e.g. Simon (1991), Stiglitz (1991).
} 
current rents, but the present discounted value of future rents. ${ }^{40}$ While this should have (but was not) fully anticipated, one might have thought that privatization was still desirable; having put the privatization behind, the enterprises could be restructured in ways that ensured the efficient deployment of resources. But the inability of government to commit itself not to provide future subsidies (especially when enterprises were too big to fail, when they provided essential public services, and/or when the corruption which was accelerated by the privatization process allowed the acquiring private parties to use the gifts they received from government to bribe government officials) often did not lead to effective restructuring. ${ }^{41}$

These episodes have also brought home the links between economic and political processes. Some of those who advocated rapid privatization before legal structures, e.g. relating to corporate governance or competition were put into place, put forth political economy arguments: they argued that these reforms would lead to a political constituency in favor of the rule of law in general and these reforms in particular. ${ }^{42}$ Critics of shock therapy (rapid privatization) argued not only that without the legal infrastructure was it unlikely that privatization would lead to increased efficiency, but that if done in the wrong way, privatization could lead to a powerful constituency against the rule of law. (Neither Bill Gates nor John D. Rockefeller were the most ardent advocates of strong competition laws!) Unfortunately for many of the economies in transition, the critics of shock therapy proved right.

\subsection{Transparency}

While the broader issues of reform have increasingly become a subject of concern to public finance economists, one topic has become the subject of intense political discussion, though again analytic work remains scarce. The issue of transparency as both a subject of and an obstacle to reform has become increasingly clear. ${ }^{43}$

While it has become politically fashionable to talk about transparency, it is clear that selective disclosure of information (secrecy) is an important instrument by which government officials attempt to create rents for themselves (like any other form of artificial scarcity, that are rents associated with limitations in the available information) and to shape public opinion. As economic theory might have

\footnotetext{
${ }^{40}$ See e.g. Stiglitz (2000b).

${ }^{41}$ These issues were of particular import in the context of privatization in the former Communist countries, where privatization often did not have the predicted effects (see Stiglitz, 1999b). The interaction between the privatization process and the political economy, including the support for the rule of law, is explored, e.g. in Hoff and Stiglitz (2001).

${ }^{42}$ See Boyko et al. (1996).

${ }^{43}$ Interestingly, while transparency has entered into the political lexicon recently, it has long been among the desiderata of good tax systems, as listed in standard textbooks. See, e.g. Stiglitz (2000a).
} 
predicted, certain agencies and government officials (e.g. in Treasury and the US Trade Representative) had greater incentives to engage in this form of behavior, and became more adept at doing so. ${ }^{44}$ This literature may represent the beginnings of a literature on the political economy of information (paralleling that on the economics of information), and it may eventually shed light on a number of seemingly anomalous behaviors. For instance, why has there been such a penchant for tax expenditures rather than direct expenditures - is it the lack of transparency of such expenditures, the difficulty of seeing who really benefits, or is the electorate really subject to a size-of-government illusion?

In some cases, economists' discussions have contributed to public confusions. For instance, in Europe, many of the problems of persistent unemployment were attributed to high social insurance taxes. Yet competitive equilibrium theory suggests that such taxes should merely result in adjustments in factor prices, not unemployment. ${ }^{45}$ It is not even clear (as is typically argued) that social security, where benefits increase in tandem with contribution, leads to reduced labor supply, i.e. forced savings may actually lead to an increased labor supply under plausible conditions. Adverse effects may arise from redistributive policies associated with social insurance - but such adverse effects would arise whether such redistribution was conducted through the tax system as well. These are the well-known trade-offs. ${ }^{46}$

\section{Concluding remarks}

At one level, there has been enormous progress and change in thinking about the role of the state in the economy. Today, everyone recognizes the importance of market failure and the need for collective action. At the same time, there is a consensus about the central place of the market in the economy. In a sense, there has emerged a consensus behind the 'Third Way,' between socialism and laissez faire. But within those wide bounds, debate continues: there is a major difference between Bush's compassionate conservatism or Clinton's New Democrats, and within Europe, differences are every bit as large.

Differences of view arise partly out of differences in models of the economy and models of the government: how large are the market failures? How large are

\footnotetext{
${ }^{44}$ For more extended discussions, see Moynihan (1998) and Stiglitz (1999a). For a discussion of the debate about transparency in the context of the East Asia crisis, see Furman and Stiglitz (1998) and Stiglitz (2002).

${ }^{45}$ To be sure, if there are high minimum wages, then an increase in social security taxes necessarily increases the marginal cost of labor - unless there are efficiency wage effects. The issue whether moderate increases in minimum wages have the adverse effects predicted by standard competitive models remains highly controversial. See Card and Krueger (1994, 1995), Deere et al. (1995), and Neumark and Wascher (1992).

${ }^{46}$ For a more extensive discussion of the issues raised in this paragraph, see Stiglitz (1999c).
} 
the public failures? How easy is it to rectify the market failures? To rectify the public failures? Sometimes, differences in views seem designed to justify particular special interests (or at least have that effect): Certainly, part of the incentive for privatization of social security in the United States, with its efficient social security administration, is the extra revenues that would be derived by the financial community; what would appear as higher transactions costs (an adverse consequence to most public policy analysts) appears as higher incomes to those marketing the new products (a positive consequence to most in the financial community.) $)^{47}$

Advances in the economics of the public sector should have shifted the balance: we now know how to design better tax systems, that reduce the dead weight loss, for any given amount of revenue raised or redistribution. We now know better how to use market mechanisms in the public sector to improve its efficiency and efficacy. Similarly, we are now more aware of the pervasiveness of market failures, and of the possible complementary relationships between the public and private sector, especially in areas like finance, where information problems are important and where market failures have repeatedly had large systemic consequences. Yet, at least in the United States, the balance of public sentiment seems to have shifted in the opposite direction. There is an interesting question - perhaps more a matter of the sociology of political activity than of conventional economics - of why that is the case.

As always, though, in matters of public policy, part of the differences in views arise from differences in values, in the relative weighting put on equity, and on alternative conceptions of equity. The latter represents one of the more important changes in public policy thinking over the past quarter of century: an evaluation of economic systems not just in terms of final outcomes (e.g. the steady state equilibrium distribution of income), but in terms of dynamics and process - we evaluate systems in terms of the equality of opportunity, in the seeming fairness of the system. Here too, practice may have outpaced theory: there has been only limited progress in welfare economics in developing the conceptual frameworks and analytic tools. ${ }^{48}$ This too remains one of the important challenges for the coming decades.

\footnotetext{
${ }^{47}$ See, e.g. Orszag and Stiglitz (2001). Murthi et al. (1999) estimate that even in the U.K., with its highly developed capital markets, benefits are reduced by around $40 \%$ as a result of transactions costs.

${ }^{48}$ Even in the limited domain of ranking stochastic processes that describe income/wealth mobility (as compared to the significant progress made in ranking income and wealth distributions (cf. Atkinson, 1970; Dasgupta et al., 1973, Rothschild and Stiglitz, 1971, on the one hand, or Kanbur and Stiglitz, 1986, on the other. For a broader discussion, see Stiglitz, 2000c).
} 


\section{References}

Andreoni, J., Erard, B., Feinstein, J., 1998. Tax compliance. Journal of Economic Literature 36, $818-860$.

Aoki, M., Murdock, K., Okuno-Fujiwara, M., 1997. Beyond the east Asian miracle: introducing the market-enhancing view. In: Aoki, M., Kim, H., Okuno-Fujiwara, M. (Eds.), The Role of Government in East Asian Development. Clarendon Press, Oxford.

Arnott, R., Stiglitz, J.E., 1986. Moral hazard and optimal commodity taxation. Journal of Public Economics 29, 1-24.

Apps, P., Stiglitz, J.E., 1979. Individualism, inequality, and taxation. Unpublished mimeo.

Atkinson, A.B., 1970. On the measurement of inequality. Journal of Economic Theory 2, 244-263.

Atkinson, A.B., Stiglitz, J.E., 1970. Lectures in Public Economics. McGraw Hill.

Atkinson, A.B., Stiglitz, J.E., 1976. The design of tax structure: direct versus indirect taxation. Journal of Public Economics 6, 55-75.

Boiteaux, 1956. Sur la gestion des monopoles publics astreints a l'équilibre budgétaire. Econometrica 24 (1), 22-40.

Boyko, M., Shleifer, A., Vishy, R.W., 1996. A theory of privatization. Economic Journal 106, 109-119.

Brito, D.L., Hamilton, J.H., Slutsky, S.M., Stiglitz, J.E., 1990. Pareto efficient tax structures. Oxford Economic Papers 42, 61-77.

Brito, D.L., Hamilton, J.H., Slutsky, S.M., Stiglitz, J.E., 1991. Dynamic optimal income taxation with government commitment. Journal of Public Economics 44, 15-35.

Brito, D.L., Hamilton, J.H., Slutsky, S.M., Stiglitz, J.E., 1995. Randomization in optimal income tax schedules. Journal of Public Economics 56 (189), 189-223.

Card, D., Krueger, A.B., 1994. Minimum wages and employment: a case study of the fast-food industry in New Jersey and Pennsylvania. American Economic Review 84 (4), 772-793.

Card, D., Krueger, A.B., 1995. Myth and Measurement: The New Economics of the Minimum Wage. Princeton University Press, Princeton.

Cremer, H., Thisse, J., 1994. Commodity taxation in a differentiated oligopoly. International Economic Review 35, 613-633.

Dasgupta, P., Sen, A.K., Starrett, D., 1973. Notes on the measurement of inequality. Journal of Economic Theory 6 (2), 180-187.

Dasgupta, P., Stiglitz, J.E., 1971. Differential taxation, public goods and economic efficiency. Review of Economic Studies 38 (114), 151-174.

Dasgupta, P., Stiglitz, J.E., 1972. On optimal taxation and public production. Review of Economic Studies 39 (1), 87-103.

Deere, D., Murphy, K.M., Welch, F., 1995. Employment and the 1990-1991 minimum-wage hike. The American Economic Review 85 (2), 232-237.

Diamond, P.A., 1998. Optimal income taxation: an example with a U-shaped pattern of optimal marginal tax rates. American Economic Review 88 (1), 83-95.

Diamond, P.A., Mirrlees, J.A., 1971. Optimal taxation and public production: I - Production efficiency. American Economic Review 61 (1), 8-27.

Emran, M.S., Stiglitz, J.E., 2000. VAT versus trade taxes: the (in)efficiency of indirect tax reform in developing countries. Mimeo.

Emran, M.S., Stiglitz, J.E., 2001. On selective indirect tax reform in developing countries. Mimeo.

Fazzari, S.M., Hubbard, R.G., Petersen, B.C., 1988. Investment, financing decisions, and tax policy. American Economic Review 78 (2), 200-205.

Furman, J., Stiglitz, J.E., 1998. Economic crises: evidence and insights from East Asia. Brookings Papers on Economic Activity 2, 1-114.

Greenwald, B., Stiglitz, J.E., 1986. Externalities in economies with imperfect information and incomplete markets. Quarterly Journal of Economics 101 (2), 229-264. 
Greenwald, B., Stiglitz, J.E., 1987. Financial structure and the incidence of the corporate income tax. Unpublished manuscript, March.

Greenwald, B., Stiglitz, J.E., 1988. Pareto inefficiency of market economies: search and efficiency wage models. American Economic Review 78 (2), 351-355.

Greenwald, B., Stiglitz, J.E., 1989. Impact of the changing tax environment on investments and productivity. The Journal of Accounting, Auditing and Finance 4 (3), 281-301.

Greenwald, B., Stiglitz, J.E., 1993. Financial market imperfections and business cycles. Quarterly Journal of Economics 108 (1), 77-114.

Greenwald, B., Stiglitz, J.E., Weiss, A., 1984. Informational imperfections in the capital markets and macroeconomic fluctuations. American Economic Review 74 (2), 194-199.

Hatta, T., 1986. Welfare effects on changing commodity tax rates toward uniformity. Journal of Public Economics 29, 99-112.

Hoff, K., Stiglitz, J.E., 1997. Moneylenders and bankers: price-increasing subsidies in a monopolistically competitive market. Journal of Development Economics 52 (2), 429-462.

Hoff, K., Stiglitz, J.E., 2001. Modern economic theory and development. In: Meier, G., Stiglitz, J.E. (Eds.), The Future of Development Economics in Perspective. Oxford University Press, Oxford, pp. 389-459.

Kanbur, R., Stiglitz, J.E., 1986. Intergenerational mobility and dynastic inequality. Princeton Woodrow Wilson School Discussion Paper in Economics: 111.

Krueger, A., 1974. The political economy of the rent-seeking society. American Economic Review 64, 291-303.

Moynihan, D.P., 1998. Secrecy: The American Experience. Yale University Press, New Haven, Connecticut.

Murthi, M., Orszag, J.M., Orszag, P.R., 1999. The charge ratio on individual accounts: lessons from the U.K. experience. Birkbeck College, University of London, Working Paper 2/99

Musgrave, R.A., 1959. The Theory of Public Finance. McGraw Hill, New York.

Myers, S.C., Majluf, N.S., 1984. Corporate financing and investment decisions when firms have information that investors do not have. Journal of Financial Economics 13, 187-221.

Naito, H., 1999. Re-examination of uniform commodity taxes under a non-linear income tax system and its implication for production efficiency. Journal of Public Economics 71 (2), 165-188.

National Performance Review, 1997. Annual report: businesslike government. National Partnership for Reinventing Government Report. October.

Neumark, D., Wascher, W., 1992. Employment effects of minimum and subminimum wages: panel data on state minimum wage laws. Industrial and Labor Relations Review 46 (1), 55-81.

Orszag, P.R., Stiglitz, J.E., 2001. Rethinking pension reform: ten myths about social security systems. In: Holzmann, R., Stiglitz, J. (Eds.), New Ideas about Old Age Security: Toward Sustainable Pension Systems in the 21st Century. The World Bank, Washington, D.C.

Pigou, A.C., 1918. The Economics of Welfare. Macmillan, London.

Ramsey, F.P., 1927. A contribution to the theory of taxation. Economic Journal 37, 47-61.

Rothschild, M., Stiglitz, J.E., 1971. Increasing risk II: Its economic consequences. Journal of Economic Theory 3 (1), 66-84.

Rothschild, M., Stiglitz, J.E., 1973. Some further results on the measurement of inequality. Journal of Economic Theory 6 (2), 188-204.

Saez, E., 2001. Using elasticities to derive optimal income tax rates. Review of Economic Studies 68 (1), 205-229.

Sah, R.K., Stiglitz, J.E., 1992. Peasants Versus City-Dwellers: Taxation and the Burden of Economic Development. Oxford University Press, New York.

Sandmo, A., 1975. Optimal taxation in the presence of externalities. Swedish Journal of Economics 77 (1), 86-98.

Sappington, D., Stiglitz, J.E., 1987. Privatization, information, and incentives. Journal of Policy Analysis and Management 6 (4), 567-581.

Simon, H., 1991. Organizations and markets. Journal of Economic Perspectives 5, 25-44. 
Slemrod, J., Yitzhaki, S., 2000. Tax avoidance, evasion, and administration. N.B.E.R. Working Paper No. 7473.

Stern, N., 1987. The effects of taxation, price control and government contracts in oligopoly and monopolistic competition. Journal of Public Economics 32, 133-158.

Stiglitz, J.E., 1973. Taxation, corporate financial policy, and the cost of capital. Journal of Public Economics 2 (1), 1-34.

Stiglitz, J.E., 1982a. Self-selection and Pareto efficient taxation. Journal of Public Economics 17, 213-240.

Stiglitz, J.E., 1982b. Ownership, control and efficient markets: some paradoxes in the theory of capital markets. In: Boyer, K.D., Shepherd, W.G. (Eds.), Economic Regulation: Essays in Honor of James R. Nelson. Michigan State University Press, pp. 311-341.

Stiglitz, J.E., 1983a. Utilitarianism and horizontal equity: the case for random taxation. Journal of Public Economics 18, 1-33.

Stiglitz, J.E., 1983b. Some aspects of the taxation of capital gains. Journal of Public Economics 21, $257-294$.

Stiglitz, J.E., 1985. The general theory of tax avoidance. National Tax Journal 38 (3), 325-338.

Stiglitz, J.E., 1986. Economics of the Public Sector, 3rd ed. W.W. Norton, New York.

Stiglitz, J.E., 1987a. Technological change, sunk costs, and competition. Brookings Papers on Economic Activity 3 (0), 883-937.

Stiglitz, J.E., 1987b. Pareto efficient and optimal taxation and the new new welfare economics. In: Auerbach, A., Feldstein, M. (Eds.), Handbook on Public Economics. North Holland: Elsevier Science Publishers, pp. 991-1042.

Stiglitz, J.E., 1987c. Design of labor contracts: economics of incentives and risk-sharing. In: Nalbantian, H. (Ed.), Incentives, Cooperation and Risk Sharing. Rowman and Allanheld, Totowa, NJ, pp. 47-68.

Stiglitz, J.E., 1988. Computerized tax collecting. In: Stein, H. (Ed.), Tax Policy in the Twenty-First Century. John Wiley and Sons, pp. 278-288, Chapter 20.

Stiglitz, J.E., 1989. The economic role of the state. In: Heertje, A. (Ed.), The Economic Role of the State. Basil Blackwell in association with Bank Insinger de Beaufort NV, Oxford.

Stiglitz, J.E., 1991. The economic role of the state: efficiency and effectiveness in the public domain. In: Hardiman, T.P., Mulreany, M. (Eds.), The Economic Role of the State. Institute of Public Administration, pp. 37-59.

Stiglitz, J.E., 1998. Pareto efficient taxation and expenditure policies, with applications to the taxation of capital, public investment, and externalities Presented at conference in honor of Agnar Sandmo. January.

Stiglitz, J.E., 1998b. The private uses of public interests: incentives and institutions. Distinguished lecture on economics in government. Journal of Economic Perspectives 12 (2), 3-22.

Stiglitz, J.E., 1998c. Inequality and growth: implications for public finance and lessons from experience in the us. In: Birdsall, N., Graham, C., Sabot, R.H. (Eds.), Beyond Tradeoffs: Market Reform and Equitable Growth in Latin America. Inter-American Development Bank.

Stiglitz, J.E., 1999. On liberty, the right to know, and public discourse: the role of transparency in public life. Oxford Amnesty Lecture. January.

Stiglitz, J.E., 1999. Quis custodiet ipsos custodes? (Who is to guard the guards themselves?) Corporate governance failures in the transition. Paper presented as keynote address at the 1999 Annual Bank Conference for Development Economics, Paris, June 23. Also published in Challenge 42(6), 26-67.

Stiglitz, J.E., 1999c. Taxation, public policy, and dynamics of unemployment. International Tax and Public Finance 6 (3), 239-262.

Stiglitz, J.E., 2000a. Economics of the Public Sector, 3rd Ed. W.W. Norton, New York.

Stiglitz, J.E., 2000b. Reflections on the theory and practice of reform. In: Krueger, A. (Ed.), Economic

Policy Reform: The Second Stage. University of Chicago Press, Chicago, pp. 551-584.

Stiglitz, J.E., 2000c. Reflections on mobility and social justice, economic efficiency, and individual 
responsibility. In: Birdsall, N., Graham, C. (Eds.), New Markets, New Opportunities? Economic and Social Mobility in a Changing World. Brookings Institution Press, Washington D.C, pp. 36-65. Stiglitz, J.E., 2002. Behind closed doors. Forthcoming.

Stiglitz, J.E., Weiss, A., 1981. Credit rationing in markets with imperfect information. American Economic Review 71 (3), 393-410.

Stiglitz, J.E., Yun, J., 2001. Integration of unemployment insurance with pension through individual savings account. Paper to be presented at the 2002 North American Winter Meeting of the Econometric Society. Atlanta, Georgia.

Varian, H., 1980. Redistributive taxation as social insurance. Journal of Public Economics 14, 49-68. World Bank, 1998. World Development Report.

World Bank, 2001. Engendering Development: Through Gender Equality in Rights, Resources, and Voice. Oxford University Press, New York. 